\title{
PRODUKSI BIOETANOL DARI BATANG TUA KELAPA SAWIT DENGAN AIR PANAS BERTEKANAN DAN BALL MILL
}

\section{Production of Bioethanol from Old Trunks of Palm Oil Using Hot Compressed Water and Ball Mill}

\author{
Suyanto $^{1, *}$, Kotetsu Matsunaga ${ }^{2}$, Hiroyuki Inoue ${ }^{2}$, Kinya Sakanishi $^{2}$ \\ ${ }^{1}$ Balai Pengkajian Bioteknologi BPPT Gedung 630 Kawasan PUSPIPTEK, \\ Setu, Tangerang Selatan, Banten 15314 \\ ${ }^{2}$ Biomass Technology Reseach Center, AIST, Hiroshima, Japan. \\ *E-mail: suyanto3399@bppt.go.id
}

\begin{abstract}
Bioethanol from oil palm trunk is one important source of energy to reduce greenhouse gas emissions and to avoid competition between the use for food and for energy as happens in other commodities. Pre-treatment of lignocellulosic biomass using sulfuric acid has high efficiency but requires high cost to neutralize the byproducts formed. Pretreatment using hot compressed water and ball mill can be used to break down the structure and composition of lignocellulose so as to increase the rate of enzymatic hydrolysis and increase the sugar yield. Hydrolysis using an enzyme cocktail with hot compressed water and ball mill can each produce $210 \mathrm{mg}$ of glucose at a temperature of $220^{\circ} \mathrm{C}$ and $200 \mathrm{mg}$ of glucose for 120 minutes at room temperature per gram of oil palm trunk. Both of these processes are environmentally friendly and have a high efficiency in the production of bioethanol from oil palm trunks.
\end{abstract}

Keywords: bioethanol, oil palm trunk, ball mill, hot compressed water, hydrolysis

\begin{abstract}
ABSTRAK
Bioetanol dari batang kelapa sawit adalah salah satu sumber energi yang penting untuk mengurangi emisi rumah kaca dan menghindari konflik kepentingan antara kebutuhan bahan pangan dan penggunaan energi sebagaimana terjadi pada komoditas lain. Pengolahan awal biomassa lignoselulosa menggunakan asam sulfat memiliki efisiensi yang tinggi tetapi membutuhkan biaya yang tinggi guna menetralisisr produk samping yang terbentuk. Pengolahan awal menggunakan air panas bertekanan dan ball mill dapat digunakan untuk memecah struktur dan komposisi lignoselulosa sehingga dapat meningkatkan laju hidrolisis enzim dan meningkatkan hasil gula. Hidrolisis menggunakan multienzim dengan air panas bertekanan dan ball mill masing-masing dapat menghasilkan $210 \mathrm{mg}$ glukosa pada suhu $220^{\circ} \mathrm{C}$ dan $200 \mathrm{mg}$ glukosa selama 120 menit pada suhu kamar per gram batang kelapa sawit. Kedua proses tersebut ramah lingkungan dan memiliki efisiensi yang tinggi pada produksi bioetanol dari batang kelapa sawit.
\end{abstract}

Kata Kunci: bioetanol, batang kelapa sawit, ball mill, air panas bertekanan, hidrolisis 


\section{PENDAHULUAN}

Biomasa lignoselulosa yang berasal dari limbah pertanian dan perkebunan adalah bahan baku yang sangat potensial untuk memproduksi bahan bakar bioetanol, di mana biomasa lignoselulosa tersebut dapat menjadi sumber energi hijau yang menjadi energi alternatif dalam krisis bahan bakar fiosil pada saat ini. Hal ini dikarenakan bahan material tersebut sangat berpotensi mengandung sejumlah gula fermentasi dari ikatan polimer selulosa dan hemiselulosa.

Dalam mengkonversi biomasa lignoselulosa menjadi bioetanol terdiri dari tiga tahapan proses (Mosier et al. 2005) yaitu tahap pertama adalah proses praperlakuan untuk memecah ikatan polimer selulosa dan hemisulosa dalam biomasa kemudian tahap kedua adalah proses hidrolisis enzimatik untuk merecovery gula fermentasi dari hasil praperlakuan dan terakhir adalah proses fermentasi untuk mengkonversi gula fermentasi menjadi bioetanol.

Komponen utama dari biomassa lignoselulosa terdiri dari selulosa, hemiselulosa dan lignin. Di antara komponen tersebut, selulosa dan hemiselulosa memiliki molekul yang terdiri dari gula dan bisa diubah menjadi etanol dengan hidrolisis enzimatis dan fermentasi. Selulosa adalah substrat kristal dan sangat sulit untuk dihidrolisis. Pemisahan hemiselulosa dan lignin dari biomasa lignoselulosa secara konvensional dengan penambahan bahan kimia seperti asam, basa atau larutan organik dilaporkan mempunyai efek yang signifikan terhadap hidrolisis enzimatik (Sun dan Cheng 2002; Wyman et al. 2005; Yang et al. 2004). Namun bahan kimia tersebut menyebabkan korosi pada reaktor dan biaya daur ulang atau penetralan pelarut (asam, basa atau larutan organik) membutuhkan biaya yang tidak sedikit dalam mengurangi efek negatif pada lingkungan. Selain itu juga menyebabkan bentukan zat baru yang dapat menekan pembentukan bioetanol oleh yeast dalam proses fermentasi.

Di sisi lain, Indonesia adalah negara tropis yang mempunyai perkebunan kelapa sawit terbesar didunia dan menunjukan peningkatan secara signifikan luas area perkebunan pada tahun terakhir ini. Usia produksi pohon kelapa sawit berkisar antara
22 hingga 25 tahun, sehingga dalam tahun ini diperkirakan lebih dari 150 juta pohon yang harus di tebang di Indonesia untuk peremajaan tanaman kelapa sawit dan jumlah tersebut akan terus beratambah setiap tahunnya. Batang kelapa sawit tersebut merupakan sumber biomasa lignoselulosa yang sangat potensial untuk dipergunakan sebagai bahan baku pembuatan bioetanol sehingga dapat mengurangi konflik terhadap sumber bahan baku bioetanol dari tanaman pangan.

Harga produksi bioetanol dari biomasa lignoselulosa masih terlalu mahal yang didasarkan pada teknologi saat ini, dan oleh karena itu diperlukan riset untuk menekan biaya dalam improvisasi hidrolisis biomasa lignoselulosa (Sun dan Cheng 2002). Pemilihan praperlakuan dari biomasa lignoselulosa merupakan hal yang utama dalam menekan biaya produksi tersebut (Wyman et al. 2005).

Pada proses hidrotermal hidrolisis dan proses mekanik (milling) dalam pemecahan struktur kimia biomasa lignoselulosa merupakan proses ramah lingkungan karena tidak ada penambahan bahan kimia dalam proses praperlakuan tersebut. Proses air panas bertekanan adalah proses yang efektif untuk hidrolisis enzimatik kayu dan biomasa limbah pertanian (Grous et al. 1986; Mosier et al. 2005; Sun dan Cheng 2002). Hal ini disebabkan air bereaksi dengan gugus asetil dalam hemiselulosa menjadi asam, sehingga dapat melarutkan hemiselulosa dari biomasa lignoselulosa (Ando et al. 2000; Liu et al. 2005; Weil et al. 1998). Untuk proses mekanik dengan menggunakan ball mill dapat menurunkan kristalinasi pada selulosa, sehingga meningkatkan kerja enzim dalam pemutusan ikatan selulosa menjadi gula sederhana (Koullas et al. 1992; Chang et al. 2000).

Dari uraian di atas, praperlakuan adalah hal yang sangat penting dalam menrubah atau menghilangkan hambatan fisik dan kimia yang berguna untuk aksesibilitas enzim dalam substrat dan dalam makalah ini akan dibahas pengaruh praperlakuan dengan ball mill dan air panas bertekanan pada hidrolisis enzimatik dalam produksi bioetanol dengan menggunakan bahan batang tua kelapa sawit. Tujuan akhir dari penelitian ini adalah pengembangan bio ethanol dengan sumber 
daya biomassa terbarukan dari limbah pabrik kelapa sawit, berdasarkan paradigma baru pengelolaan limbah sebagai profit center, manajemen ramah lingkungan, dan minimisasi limbah

\section{BAHAN DAN METODE}

Batang kelapa sawit yang dipergunakan dalam penelitian ini berasal dari Perkebunan Kelapa Sawit PTP Nusantara VII, Indonesia. Batang kelapa sawit yang sudah dipisahkan dari kulit luar dan dikeringkan selama 24 jam dalam oven $60{ }^{\circ} \mathrm{C}$, kemudian dicacah menjadi chip. Chip tersebut dihaluskan menggunakan choper dan dalam penelitian ini dipergunakan ukuran antara 500 sampai $1000 \mu \mathrm{m}$. Bahan dicampur secara merata untuk menghindari perbedaan komposisi dalam percobaan dan disimpan dalam kondisi kering sebelum digunakan. Pada saat dipergunakan bahan batang kelapa sawit tersebut dikeringkan dalam vakum dryer pada suhu $40^{\circ} \mathrm{C}$ selama 3 hari.

\section{Praperlakuan dengan ball mill}

$\begin{array}{ccc}\text { Bahan batang } & \text { kelapa sawit } \\ \text { dihaluskan } & \text { dengan menggunakan }\end{array}$ Planetary Micro mill pulverisette 5 (Fritsch, Germany). Sebanyak 20 gram bahan dihaluskan dengan kecepatan 250 rpm selama 120 menit menggunakan siklus 10 menit penghalusan dan 10 menit berhenti sementara pada suhu ruang.

\section{Praperlakuan dengan air panas bertekanan}

Bahan batang kelapa sawit sebanyak 20 gram dan air $180 \mathrm{~mL}$ dicampur dalam wadah $300 \mathrm{~mL}$ stainless steel autoclave dengan satu pengaduk jenis turbin. Gas nitrogen untuk menghilangkan udara didalam autoclave dengan tekanan $5 \mathrm{MPa}$. Autoclave dipanaskan dan dipertahankan selama 30 menit dengan deviasi $\pm 2{ }^{\circ} \mathrm{C}$ pada suhu yang ditentukan $\left(160-240{ }^{\circ} \mathrm{C}\right)$. Waktu pemanasan bahan baku diprogram sebesar $16{ }^{\circ} \mathrm{C} /$ menit. Pada akhir reaksi autoclave didinginkan sampai suhu ruang. Pengambilan fraksi padat menggunakan filtrasi, dan dicuci dengan air demin kemudian diliophilisasi.

\section{Hidrolisis enzimatik}

Hidrolisis enzimatik menggunakan multienzim yang mengandung 10 dan 40 FPU Acremonium cellulose (Meiji Seika Co,
Japan), 0,04 mL Optimash BG (Genencor International, USA) per gram bahan kering. Dalam standar perhitungan, $1 \mathrm{~mL}$ multienzim dilarutkan dalam $50 \mathrm{mM}$ buffer asetat $(\mathrm{pH}$ 5,0). Campuran reaksi diinkubasi dalam shaker pada $45^{\circ} \mathrm{C}$ selama 72 jam. Percobaan dilakukan sebanyak dua kali. Hasil hidrolisis disentrifugasi untuk dipisahkan fase cair dan residu dan dianalisa kadungan glukosa dan silosa.

\section{Fermentasi bioetanol}

Pada akhir hidrolisis enzimatik, gula yang terbentuk langsung difermentasi menggunakan Saccharomyces cerevisiae IR-2 untuk memproduksi bioetanol. Waktu inkubasi selama 36 jam pada $30^{\circ} \mathrm{C}$ menggunakan shaker.

\section{Analisa}

Analisa komposisi kimia batang kelapa sawit menggunakan metode NREL (Sluiter et al. 2005). Glukosa dan silosa dianalisa menggunakan HPLC dengan sebuah refractive index detector (RI2031Plus, JASCO, Japan) dan kolom Aminex HPX-87P $(7,8 \mathrm{~mm}$ I.D. $30 \mathrm{~cm}$, BioRad, USA) dengan Carbo-P microguard cartridge. Fase gerak menggunakan air demin dengan kecepatan aliran 1 $\mathrm{mL} / \mathrm{min}$ pada $80^{\circ} \mathrm{C}$.

\section{HASIL DAN PEMBAHASAN}

Dalam penelitian ini semua perhitungan didasarkan pada berat kering batang kelapa sawit. Komposisi batang kelapa sawit adalah $47 \%$ selulosa, $32 \%$ hemiselulosa, $17 \%$ lignin, $3 \%$ ekstraktif dan $1 \%$ abu, yang dirujuk dari prosedur analitik dari NREL.

\section{Hidrolisis enzimatik pada praperlakuan ball mill}

Kemampuan enzimatik pada bahan batang kelapa sawit yang sudah di treatment menggunakan ball mill dievaluasi dengan berbagai komposisi enzim yang ditunjukkan dalam Tabel 1 . Hidrolisis dengan multienzim yaitu ACC(40FPU) dan OBG menunjukkan hasil yang lebih besar baik glukosa dan silosa dari komposisi enzim lainnya, sehingga komposisi multienzim tersebut dipergunakan sebagi standar dalam penentuan hidrolisis enzimatik pada substrat selanjutnya. 
Tabel 1. Perbedaan berbagai hidrolisis enzimatis pada hasil praperlakuan ball mill pada batang kelapa sawit

\begin{tabular}{lcc}
\hline \multirow{2}{*}{ Enzim } & \multicolumn{2}{c}{ Kandungan gula $(\mathrm{mg} / \mathrm{g})$} \\
\cline { 2 - 3 } & Glukosa & Silosa \\
\hline ACC(10 FPU) & 175 & 38 \\
ACC (40 FPU) & 189 & 69 \\
ACC (10 FPU) +OBG & 181 & 116 \\
ACC (40 FPU) +OBG & 200 & 121 \\
\hline
\end{tabular}

$\mathrm{ACC}=$ Acremonium cellulose $; \mathrm{OBG}=$ Optimash $\mathrm{BG}$

Dari Tabel 1. menunjukan OBG dapat memecah ikatan selulosa disamping memecah ikatan hemiselulosa menjadi silosa sedangkan ACC merupakan selulase komersial yang memiliki aktivitas $\beta$ glucosidase tinggi dibandingkan dengan konvensional selulase dari Trichoderma spesies lainnya (Yamanobe et al. 1990). Hidrolisis enzimatik batang tua kelapa sawit tanpa pretretment ball mill dengan menggunakan ACC menghasilkan glukosa sebesar $72 \mathrm{mg} / \mathrm{g}$ substrat (data tidak ditunjukkan). Dari data tersebut menunjukkan bahwa glukosa dari hidrolisis ezimatik dengan praperlakuan ball mill meningkat secara signifikan. Hal ini disebabkan selulosa mikrofibril pada dinding sel batang tua kelapa sawit terganggu oleh efek mekanik dari ball mill sehingga disebut efek mechanochemical (Ago et al. 2004). Dari hasil penelitian ini menunjukkan bahwa ada hubungan yang erat antara kerja enzimatik dengan mechanochemical yang membuat struktur jaringan selulosa-hemiselulosa-lignin terganggu atau putus, sehingga dapat memaksimalkan kerja enzim.

\section{Pengaruh perlakuan air panas bertekanan}

Praperlakuan air panas bertekanan dilakukan pada lima tingkat suhu pada kisaran $160-240^{\circ} \mathrm{C}$ selama 30 menit. Hasil dari hidrolisis enzimatik pada gula fraksi larut dan residu dirangkum pada Tabel 2 . Peningkatan xilan terlarut dari praperlakuan batang kelapa sawit menggunakan air panas bertekanan terjadi di atas $160^{\circ} \mathrm{C}$. Hal ini menunjukkan secara tidak langsung bahwa hemiselulosa terdegradasi dan membuat struktur jaringan selulosahemiselulosa-lignin terputus sehingga
Tabel 2. Glukosa dan silosa dari fraksi cair dan residu batang kelapa sawit pada hasil praperlakuan dengan air panas bertekanan

\begin{tabular}{ccccc}
\hline \multirow{2}{*}{$\begin{array}{c}\text { Suhu } \\
\left({ }^{\circ} \mathrm{C}\right)\end{array}$} & \multicolumn{3}{c}{ Kandungan gula (mg/g) } \\
\cline { 2 - 5 } & \multicolumn{2}{c}{ Fraksi larut } & \multicolumn{2}{c}{ Residu } \\
\cline { 2 - 5 } & Glukosa & Silosa & Glukosa & Silosa \\
\hline 160 & 0,82 & 1,00 & 92 & 66 \\
180 & 0,92 & 1,82 & 149 & 85 \\
200 & 0.93 & 1,62 & 182 & 87 \\
220 & 0,72 & 3,19 & 210 & 90 \\
240 & 0,60 & 1,20 & 162 & 70 \\
\hline
\end{tabular}

pembentukan glukosa dari selulosa dari hidrolisis enzimatis meningkat sampai pada suhu $220^{\circ} \mathrm{C}$ (Tabel 2). Dari hasil percobaan tersebut dapat diketahui, meningkatnya kemampuan enzim dalam memutus ikatan polimer selulosa yang berakibat bertambahnya kandungan glukosa dalam residu berkaitan dengan putusnya ikatan hemiselulosa yang disebabkan oleh efek hidrotermal.

Sedangkan pada suhu di atas $220^{\circ} \mathrm{C}$, hasil silosa pada fraksi larut sangat terpengaruh pada dekomposisi hemiselulosa menjadi furfural dan turunannya sehingga jumlah silosa menurun. Demikian halnya dengan jumlah glukosa mengalami penurunan yang sangat signifikan. Berdasarkan data pada Tabel 2 jumlah glukosa maksimum pada hidrolis enzimatik batang kelapa sawit dengan praperlakuan air panas bertekanan terjadi pada suhu $220^{\circ} \mathrm{C}$ dengan jumlah glukosa sebesar $210 \mathrm{mg} / \mathrm{g}$ substrat. Pada suhu $240^{\circ} \mathrm{C}$ kandungan glukosa menurun sehingga pada suhu tersebut penggunaan multienzim (ACC (40 FPU) dan OBG) terjadi penurunan, karena terdekomposisinya selulosa menjadi bahan yang lain. Hal ini sesuai dengan hasil yang dilaporkan oleh Ando et al. (2000) pada dekomposisi biomasa dalam air panas bertekanan.

\section{Fermentasi bioethanol}

Fermentasi bioetanol menggunakan Saccharomyces cerevisiae IR-2 pada hasil hidrolisis enzimaitis multienzim (ACC (40 FPU) dan OBG) dari praperlakuan batang kelapa sawit menggunakan ball mill disajikan pada Gambar 1, di mana semua 


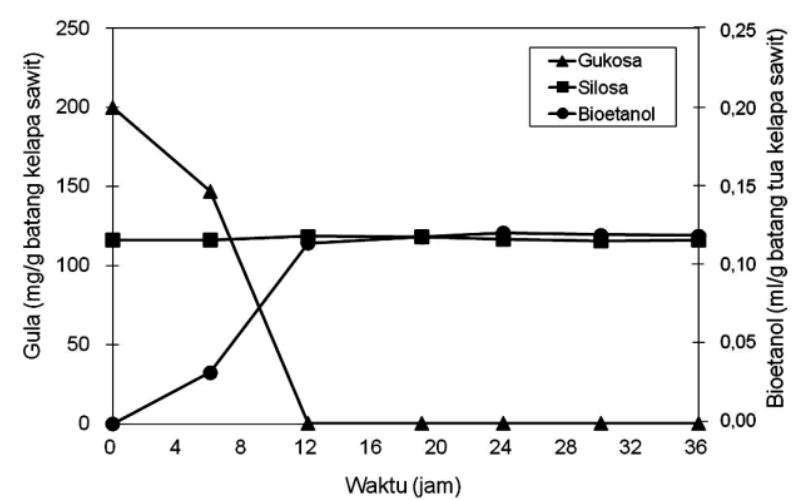

Gambar 1. Hasil fermentasi bioetanol dari praperlakuan batang kelapa sawit dengan ball mill

glukosa habis terkonversi menjadi bioetanol pada jam ke 12, sedangkan silosa tetap kandungannya sampai jam ke 36. Hal ini dikarenakan strain Saccharomyces cerevisiae IR-2 hanya dapat mengkonversi glukosa menjadi bioetanol. Sedangkan fermentasi bioethanol pada hasil hidrolisis enzimatis dari residu praperlakuan batang kelapa sawit dengan air panas bertekanan pada suhu $220^{\circ} \mathrm{C}$ (Gambar 2), juga menunjukkan hasil glukosa dapat terkonversi sempurna menjadi bioetanol. Namun waktu fermentasinya lebih lama yaitu pada jam ke20 terkonversi sempurna dan kandungan silosa sama dengan praperlakuan menggunakan ball mill. Waktu fermentasi yang lebih lama tersebut disebabkan oleh zat inhibitor seperti furfural dan asam asetat (data tidak ditunjukkan) yang terbentuk selama proses air panas bertekanan.

Dari hasil tersebut (Gambar 1 dan Gambar 2) di mana kedua praperlakuan (ball mill dan air panas bertekanan) menunjukkan produktivitas bioetanol yang tinggi dan hampir sama dari gula fermentasi dalam hidrolisat enzimatik batang kelapa sawit yaitu $0,12 \mathrm{~mL} / \mathrm{g}$ batang tua kelapa sawit pada praperlakuan menggunakan ball mill dan $0,13 \mathrm{~mL} / \mathrm{g}$ batang tua kelapa sawit dengan menggunakan preteratment air panas bertekanan.

Dari hasil tersebut di atas dapat memberi gambaran potensi batang kelapa sawit untuk dikonversi menjadi bioethanol dengan produktivitas yang tinggi tanpa menggunakan bahan kimia, sehingga lebih ramah lingkungan dan penggunaan energi hijau dapat terwujud.

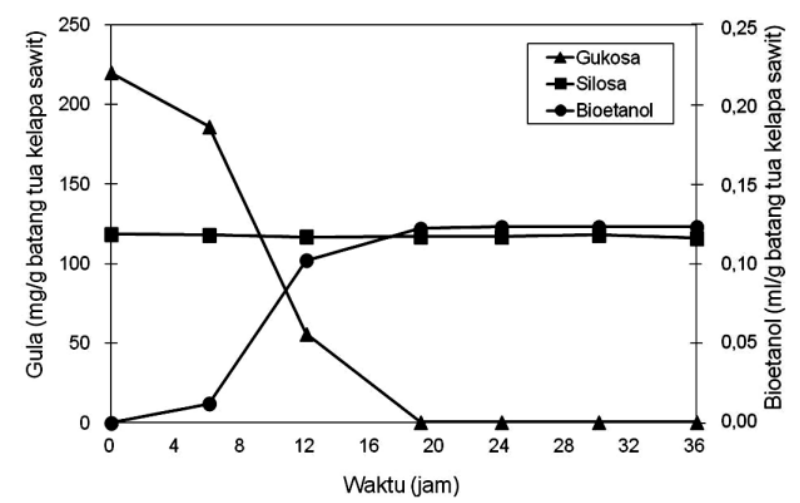

Gambar 2. Hasil fermentasi bioetanol dari praperlakuan batang kelapa sawit dengan air panas bertekanan

\section{KESIMPULAN}

Batang kelapa sawit yang ditreatment dengan air panas bertekanan menghasilkan glukosa yang lebih tinggi $0,01 \mathrm{~mL} / \mathrm{g}$ batang tua kelapa sawit dari penggunaan ball mill. Namun dalam air panas bertekanan terbentuk zat baru seperti furfural dan asam asetat yang dapat menghambat proses fermentasi sehingga membutuhkan waktu yang lebih lama untuk konversi menjadi bioetanol, sedangkan ball mill membutuhkan energi yang besar untuk proses penghalusan batang kelapa sawit. Dengan mengkobinasikan praperlakuan ball mill dengan waktu yang pendek dan air panas bertekanan dengan suhu rendah merupakan teknologi alternatif yang perlu dipertimbangkan untuk skala yang lebih besar.

\section{UCAPAN TERIMA KASIH}

Terima kasih diucapkan kepada NEW Energi Foundation, Japan yang telah membiayai penelitian ini melalui Asia Biomass Energy Researchers Invitation Program.

\section{DAFTAR PUSTAKA}

Ando $H$, Sakaki T, Kokusho T, Shibata M, Uemura Y, Hatate $Y$ (2000) Decomposition behavior of plant biomass in hot-compressed water. Industrial and Eng Chem Res 39:3688-3693

Ago M, Endo T, Hirotsu T (2004) Crystalline 
transformation of native cellulose from cellulose I to cellulose II polymorph by a ball milling method with a specific amount of water. Cellulose 11:163-167

Chang VS, Holtzapple MT (2000) Fundamental factors affecting biomass enzymatic reactivity. Appl Biochem Biotechnol 84:5-37

Grous WR, Converse AO, Grethlein HE (1986) Effect of steam explosion pretreatment on pore size and enzymatic hydrolysis of poplar. Enzyme MicrobTechnol 84:274-280

Koullas DP, Christakopoulos P, Kekos D, Macris BJ, Koukios EG (1992) Correlating the effect of pretreatment on the enzymatic hydrolysis of straw. Biotechnol Bioeng 39:113-116

Liu C, Wyman CE (2005) Partial flow of compressed-hot water through corn stover to enhance hemicellulose sugar recovery and enzymatic digestibility of cellulose. Biores Technol 96:19781985

Mosier N, Wyman CE, Dale B, Elander R, Lee YY, Holtzapple M, Ladisch M (2005) Features of promising technologies for pretreatment of lignocellulosic biomass. Biores Technol 96:673-686

Sluiter A, Hames B, Ruiz R, Scarlata C, Sluiter J, Templeton D (2005)
Determination of structural carbohydrates and lignin in biomass. NREL Biomass. http://www.nrel.gov/biomass/analytical _ procedures.html\#lap-002. Diakses 10 November 2010

Sun Y, Cheng J (2002) Hydrolysis of lignocellulosic materials for ethanol production. Biores Technol 83:1-11

Wyman CE, BE Dale, RT Elander, M Holtzapple, MR Ladisch, YY Lee (2005) Coordinated development of leading biomass pretreatment technologies. Biores Technol 96:19591966

Weil JR, Sarikaya A, Rau SL, Goetz J, Ladisch CM, Brewer M, Hendrickson R, Ladisch LR (1998) Pretreatment of corn fiber by pressure cooking in water. Appl Biochem Biotechnol 73:117

Yamanobe T, Hiraishi J, Kruus I (1990) Improvement of fungal strain Y-94, a cellulolytic enzyme hyperproducer, and enzymatic saccharification of exploded wood. Agric Biol Chem 54:535-536

Yang B, Wyman CE (2004) Effect of xylan and lignin removal by batch and flow through pretreatment on the enzymatic digestibility of corn stover cellulose', Biotechnol Bioeng 86:88-95 